Note from James D. Thomson, Editor-in-Chief, Journal of Pollination Ecology

This paper inaugurates a new category for the Journal of Pollination Ecology. Its history is relevant. Over several decades, Professor C. Eugene Jones oversaw regular censuses of flower-visiting animals to riparian populations of the endangered California plant Eriastrum densiflorum, which had become vulnerable because of stream impoundments. This visionary program of study resulted in several master's theses from the California State University at Fullerton. A summary was submitted to JPE. Reviewers were unconvinced by the statistical analyses and some aspects of the paper's discussion. These perceived shortcomings would usually be addressed through revision and resubmission, but in this case, exigent personal issues prevented the authors from reworking the paper. I decided that JPE could not publish the paper as submitted and retain its status as a peer-reviewed journal. On the other hand, I firmly believe that long-term data sets have special, intrinsic value, particularly because so much attention is now focused on the question of pollinator declines. Therefore, I am proposing a new category of publication, Noteworthy Data Sets. For the first such offering, I have edited the Hoffman et al. manuscript as follows.

I have made minor adjustments to the Introduction and Methods sections to improve clarity and concision. I have retained all submitted Figures and Tables, along with all cited references. I have removed the description of statistical methods, the Results section, and the Discussion. These portions, basically unedited, will appear as online appendices, accompanied by a disclaimer that these sections should not be regarded as having been endorsed by peer review.

In adopting this unorthodox partitioning of material, I hope to provide an easily found foothold for this study in the peer-reviewed literature. Any researchers who are stimulated to learn more, or who might even want to extend the study with further investigations, should be able to find the information they need in the Fullerton theses and the other cited references. The online materials, despite the caveats, may be useful in outlining the general approach taken by Jones and coauthors.

\title{
SPATIOTEMPORAL VARIATION IN POLLINATOR TAXA ON THE SANTA ANA RIVER WOOLY STAR ERIASTRUM DENSIFOLIUM SSP. SANCTORUM (MILLIKEN) MASON (POLEMONIACEAE)
}

\author{
C. Eugene Jones ${ }^{1}$, Fern L. Hoffman ${ }^{1}$, Patricia Nunes-Silva ${ }^{2}$, Robert L. Allen ${ }^{1}$, Axhel Muñoz ${ }^{1}$, Marion \\ Erickson ${ }^{1}$, Douglas Stone ${ }^{1}$, and Youssef Atalla ${ }^{1}$ \\ ${ }^{l}$ Department of Biological Science, California State University, Fullerton, Ca 92831 \\ ${ }^{2}$ School of Environmental Sciences, University of Guelph, 50 Stone Road East, Guelph - Ontario, NlG 2Wl, Canada
}

\begin{abstract}
Flood control, via the construction of the Seven Oaks Dam in the Santa Ana River in southern California, has altered habitat in the downstream alluvial wash community and jeopardized the persistence of pioneer plant species that rely on periodic flood-scouring and sand recharge. One species, Eriastrum densifolium ssp. sanctorum ("Eriastrum"), an endangered perennial, has been greatly affected and persists in spatially separated populations on successional vegetation terraces. We made "dawn to dusk" observations of pollinators in three phenological stages at four sites, representing young and old seral stages, to identify primary pollinators and to elicit daily, site, and seasonal patterns of visitors. Data were compared to previous observations and correlated with annual rainfall to determine long-term trends. Shifts in pollinator taxa have occurred, with some consistency through time and space, during nine years. The sites with the highest pollinator abundance (older sites) are least suited to Eriastrum. Hummingbirds (prevalent in early season) and the Acton giant flower-loving fly (prevalent in late season) have been consistently present across years, whereas other taxa have varied. A shift from native bees to non-native bees has occurred, although native bees in the families Halictidae and Apidae (Micranthophora and Melissodes) remain important. In general, there was no correlation between taxa abundance and rainfall. Eriastrum appears to be a generalist able to take advantage of the behaviour, cycling, and availability of diverse pollinators daily, seasonally, and annually.
\end{abstract}

Keywords: Pollination, Santa Ana River woolly star, pollinators, rare species, Seven Oaks Dam, native bee declin 


\section{INTRODUCTION}

Throughout the world, biodiversity is declining at an alarming rate. The principal anthropogenic causes are habitat loss or alteration, fragmentation, and increasing urbanization (Zedler 200I; Burkle et al. 2013). The results are, ultimately, environmental homogeneity and reduced biotic productivity (Stanford et al. 1996), impacting several ecosystem services, e.g. pollination (Kremen et al. 2002; De Marco \& Coelho 2004; Díaz et al. 2006; Kremen et al. 2007; Vanbergen \& the Insect Pollinators Initiative 2013; Potts et al. 20I6). The mutualistic interaction between pollinator-dependent angiosperms and animals may affect community dynamics and terrestrial ecosystem function (Ambrose \& Kevan 1990; Kearns \& Inouye 1997; Allen-Wardell, et al. 1998; Bronstein et al. 2006; Waser \& Ollerton 2006; Tepedino, et al., 20I4; Bailey \& Kevan, 2017). Worldwide, around 90\% of angiosperms are considered to be animal pollinated (Kearns et al. 1998; Ollerton et al. 2011).

One dramatic anthropogenic modification is the regulation and alteration of natural river flows, resulting in impacts to downstream environs and biota, as well as those biota surrounding and underlying the impoundments (Stanford et al. 1996). The Seven Oaks Dam, near the City of Highlands, was inaugurated in 2000 and caused the loss of periodic scouring and clean sand deposition, necessary for the renewal of alluvial wash habitat (Burk et al. I988). It was constructed despite predicted impacts for flood-plain restricted species, like the Santa Ana River Woolly Star plant (Eriastrum densifolium ssp. sanctorum (Milliken) H. Mason, Polemoniaceae; hereafter "Eriastrum") (U.S. Army Corps 2000), which is considered to be one of California's most endangered plants (York 1987).

Eriastrum occurs and is endemic to the Santa Ana River drainage. Historically, Eriastrum occurred from the foothills of the San Bernardino Mountains in San Bernardino County and extended throughout the relic alluvial habitat to northern Orange County (Zembal and Kramer 1984; Burk et al. 1987). However, due to habitat loss and degradation resulting from urbanization, flood control, off-road vehicle use, sand and gravel mining, and colonization by invasive species (Burk et al. 1988), distribution is now restricted to scattered patches just north of Redlands, San Bernardino County, California. Eriastrum is specialized to require disturbance for habitat and/or regeneration (Pickett \& White 1985) and is therefore restricted to periodically flood-scoured and alluviumdeposited Soboba washed sands, classified as Entisols (Burk et al. 1988; Burk, et al. 2007).

Eriastrum is exclusively reliant on the services of animal vectors for reproduction (Burk, et al. I989; Burk \& Jones 1993; Erickson 1993; Stone 1995; Brunell 1997), thus, the absence of pollinators could quickly result in the extirpation of the already perilously low remnant populations. Populations in fragmented landscapes become progressively more isolated and reduced in size, and face increasing probability of extinction (Young et al. I996; Tepedino et al. 2014). When plants such as Eriastrum are reduced to small and isolated populations, biotic interactions are reduced (Aizen \& Feinsinger 1994; Brys et al. 2004) including pollination (Mustajarvi et al. 200I; Aizen et al. 2002), especially when floral displays are reduced (Fischer \& Matthies 1997).

Furthermore, rare plants, especially narrow endemics such as Eriastrum, are more easily pushed to extinction by stochastic events (Schemske et al. 1994; Fischer \& Matthies 1997; Steffen-Dewenter \& Tscharntke 1999) including variation in pollinator abundance (Goodwillie 200I; Ashman et al. 2004). Therefore, conservation strategies need to integrate research on the factors that diminish reproductive success (Godt \& Hamrick, 1995; Bosch et al. 1998).

Long-term studies of plant pollinator interactions are rare. They have generally been restricted to either an examination of relative visitor abundance or per-visit effectiveness in transferring pollen, but rarely both (Spears 1983; Schemske \& Horvitz 1984; Galen et al. 1987; Herrera 1989). Pollinator effectiveness is a combination of both and requires integration of all the factors effecting successful reproduction (Aigner 2005). Few studies address the intra- and interspecific behaviours of pollinators, which would seem to influence the presence of other pollinators daily and seasonally (Aigner 2005) and accordingly become a critical component dictating pollinator demographics.

\section{Spatiotemporal variation in pollinators}

In addition, floral visitor assemblages shift through time and space (Potts et al. 2003; Basilio et al. 2006; Alarcon et al. 2008). This spatiotemporal variation occurs annually, seasonally, and daily. In fact, year-to-year variation and seasonal variation in relative abundances are considered the norm in many species due to variable climatic conditions (Herrera 1989; Petterson 199I; Fleming et al. 200I; UNFAO 2008).

In arid and semi-arid areas, plants typically bloom when water resources and temperatures are amenable; therefore, opportunities for sexual reproduction are brief. Weather conditions of high winds, fluctuating temperatures, and variable precipitation can also affect insect visitation (Robertson 1895; Motten 1986; Herrera 1995; Proctor et al. 1996; Ollerton \& Crammer 2002). In generalized pollination systems, habitat type has also been found to influence abundance and diversity (Fleming et al. 200I) and population size strongly affected abundance (Sih \& Baltus I987; Brys et al. 2004). Since Eriastrum occurs in both young and older vegetation assemblages, these habitat differences would be expected to have an influence on pollinators' presence and abundance. Discrete small populations, as found in Eriastrum, also may restrict the array and abundance of flower-visiting fauna (Jennersten 1988; Lamont et al. 1993; Kearns et al. 1998).

The reproductive biology of Eriastrum has been studied during nine years; across early, mid, and late phenologies; under variant environmental conditions; and within both young and old seral habitat stages (Muñoz, I99I; Erickson, 1993; Stone, I995; Dorsett 1996; Atallah 200I; Hoffman, 2010). Rarely has such long-term pollination research been conducted on plant species at the same location. 


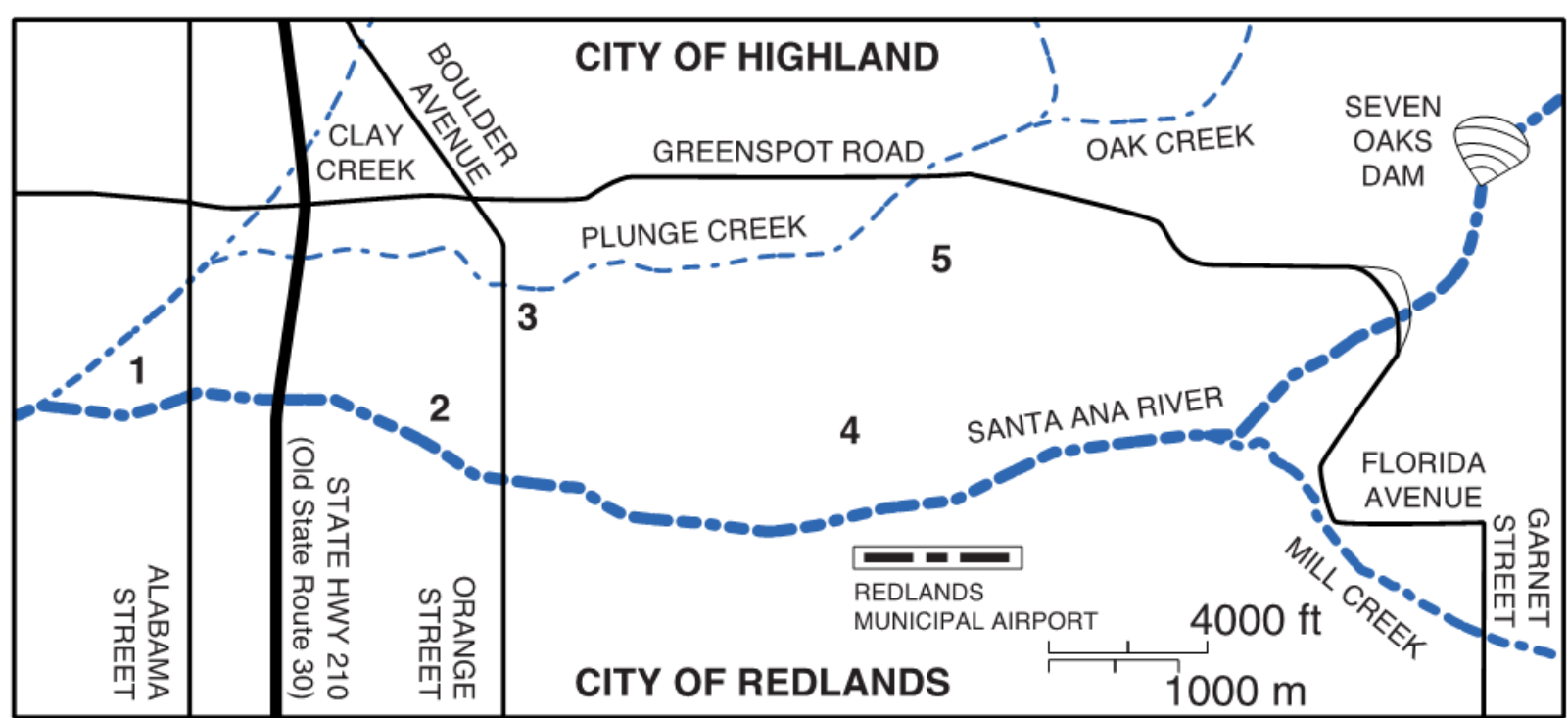

1, 2, 3, 4, 5 Study Sites

- Street

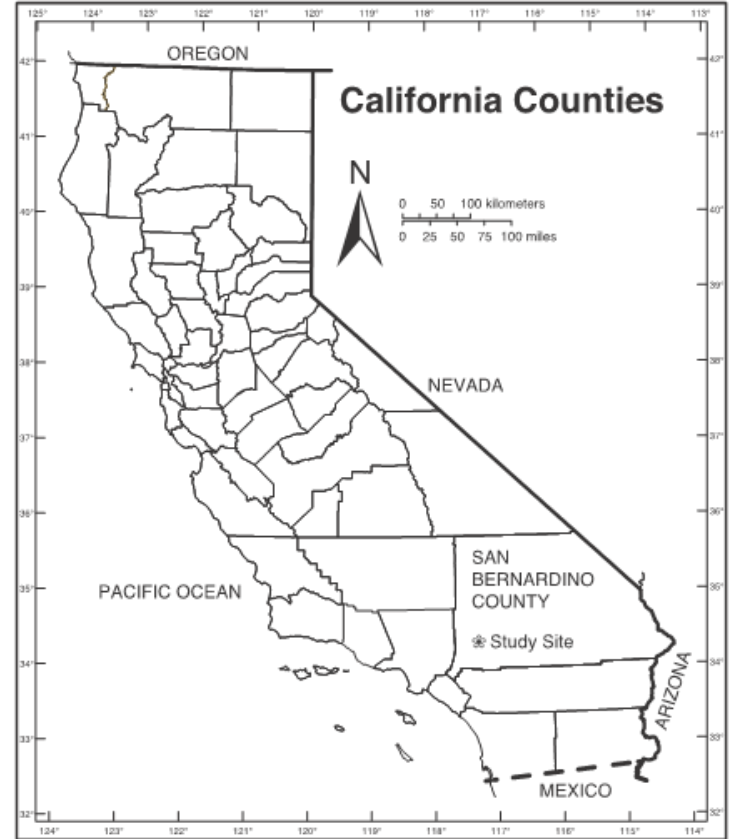

Figure I. The Santa Ana River Wash Area (San Bernardino County, California) in which all known individuals of Eds occur. Sites I, 2, 3 and 5 indicate locations of permanent demographic plots employed in this study. Site 4, although included in previous research, does not presently support

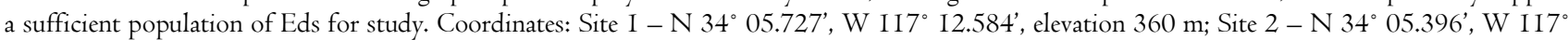
I I.022', elevation 387 m; Site 3 - N 34 06.0I I', WII7' I0.832', elevation 396 m: Site 4 - N 34 05.299', W II7 I0.I64', elevation unrecorded; Site 5 - $34^{\circ} 07.034^{\prime}, \mathrm{W} 117^{\circ}$ II.509', elevation $457 \mathrm{~m}$.

The aims of this research were I) to determine the principal pollinators in each year; 2) assess variation in pollinator taxa and abundances across seasons and years, identifying trends; 3 ) check for correlation among pollinators' abundances and annual and critical period rainfall (rainfall occurring in the critical months of germination and growth for Eriastrum, January, February, and March) and daily temperatures; and 4) assess the relationship between the successional stage of the habitat and pollinator suitability. We examined how pollinator species abundances varied over time, particularly looking for correlations with mean annual precipitation.

\section{MATERIALS AND METHODS}

\section{Plant species}

Eriastrum is a short-lived perennial, woody, branched subshrub (height ranges from $25-75 \mathrm{~cm}$ ) with an approximate life expectancy of three to five years (Burk et al. 1987). It has older woody growth and young herbaceous growth, with branching occurring each growing season. The common name refers to the thick pubescence of lannate hairs on the leaves and inflorescences. The flowers are clustered in bracheate heads, have a salver form shape, a light scent, and are protandrous with blue or cream pollen. Corollas are lavender 
with occasional pinks and whites, with a blooming period from late May to mid-August, with peak flowering in June.

\section{Site location}

Dawn-to-dusk pollination studies were conducted at five sites within the Santa Ana River floodplain, north of Redlands, San Bernardino County, California, (Fig. I). These sites were selected to represent various successional habitat ages and to include the presence of 100 or more plants (Burk et al. 1987). Site I and 2 were last scoured in the 1969 flood and are considered to be young successional sites (Burk \& Jones 1993); Site 3 is considered an older successional stage terrace created in the 1938 and either the I862 or I867 floods; and Site 5 is also considered an older terrace established by either the I862 or I867 floods (Burk \& Jones 1993).

\section{Site characteristics}

The substratum of younger sites comprises deposited alluvium containing little to no silt or clay and is classified as Soboba stony, loamy sand with a high porosity and permeability (Wheeler 199I). The substratum of older sites contains more fine particulate (Wheeler 199I).

Holland (1986) classifies the vegetation as successional stages of Riversidian Alluvial Fan Sage Scrub Community (Holland 1986), variously degraded by human disturbance.

The climate is Mediterranean, consisting of cool wet winters and warm dry summers (Schoenherr 1995). The mean annual rainfall for the city of Redlands is $34.43 \mathrm{~cm}$ (maximum $=68.58 \mathrm{~cm}$; minimum $=12.34 \mathrm{~cm}$. The mean annual temperature is $17.54^{\circ} \mathrm{C}$ (average maximum $=25.61^{\circ} \mathrm{C}$; average minimum $=9.56^{\circ} \mathrm{C}$ ) with a statistical monthly high of $34.72^{\circ} \mathrm{C}$ in July and low of $4.06^{\circ} \mathrm{C}$ in January (Western Regional Climate Center 2009).

Pollinator studies
We observed flower visitors on Eriastrum in a series of three, three-day "dawn-to-dusk" (0600 to I800) "pollination studies" (nine total periods). A team of observers conducted each of the three-day observation sets during the early $(25 \%$ of plants in bloom), mid (75-95\% of plants in bloom) and late ( $25 \%$ of the plants in bloom) blooming periods, which were compared between 1995 and 2008. A pollinator was defined as an animal that actually landed on and came into contact with the pollen and/or stigma of the flower. Visitors that alighted and did not contact the reproductive structures were not considered.

Three subpopulations at each of the study sites were chosen on the basis of ease with which one person could observe all visitation to $15-20$ plants. We identified each pollinator to family, and if possible, to genus, species, and sex. We recorded numbers of visitations at the first of the three subpopulations from the top of the hour, until ten minutes after the hour, then rotated to the next subpopulation and recorded observations from 20 minutes after the hour until 30 minutes after the hour, then rotated to the third population and recorded observations from 40 minutes after the hour to 50 minutes after the hour. This process continued from 06:00 to 18:00, repeating every hour. On each of the three days, the initial subpopulation was rotated to a different starting population. The total observation time for all three observation periods of 234 hours. Total monthly precipitation for the growing season (occurring from July of the previous year to June of the study year) for 1995 and 2008 was recorded in Redlands. Notes on pollinator behaviour and ambient conditions, including hourly temperatures, cloud cover, and wind conditions, were also recorded. Insect visitors were identified using a reference collection developed by Stone for his work on Eriastrum (Stone 1995). Data from studies of other years were included to define the pollinators: 2000 (Atallah 200I), I993 and I994 (Stone I995), I99I and I 992 (Erickson I993), 1989 and I990 (Muñoz I99I).

\section{Comparison of Total Pollinator Visits for Sites: 1, 2, 3, 5 In 1995, 2000, 2008}

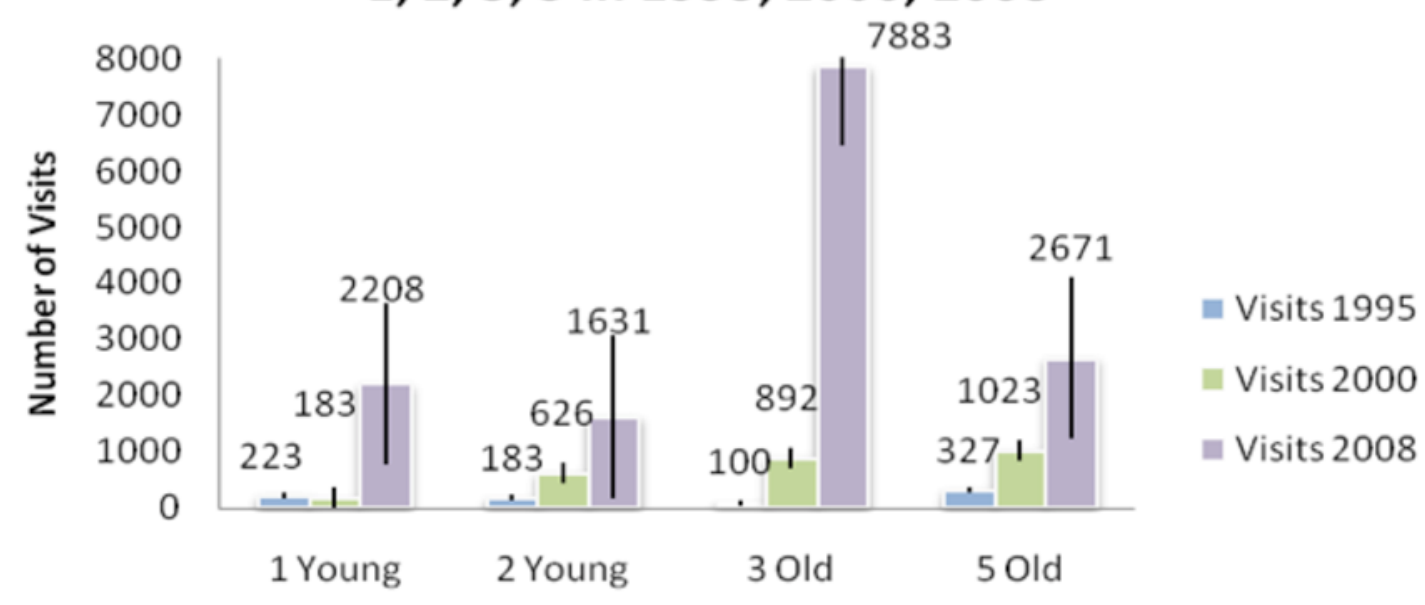

Sites

FIGURE 2. Number of recorded visits of all pollinators for Sites I \& 2 (Young) and Sites $3 \& 5$ (Old) for observation years of 1995, 2000, and 2008. 


\section{ACKNOWLEDGEMENTS}

We thank Douglas Yanega, Senior Museum Scientist, University of California, Riverside, for identifying the sweat and digger bees in the photographs. Special thanks to Peter Kevan for his editorial suggestions.

\section{APPENDICES}

Additional supporting information may be found in the online version of this article:

APPENDIX I. The description of statistical methods, the Results section, and the Discussion. These sections should not be regarded as having been endorsed by peer review.

TABLE I. Primary and secondary pollinators from each site arranged by year of observation. MIC - Long-tongued Digger bees, LEP butterflies and moths, RA - Acton Giant Flower-loving Fly, HUM - Hummingbirds, HYLE - White-lined Spinx Moth, BOM - Bumble bees, BOMC - California bumble bee (Bombus Californicus), HAFA - Halictus farinosus (Halictidae), HATR - Halictus tri[artitus (Halictidae), HAL Sweat bees (Halictidae), MEL - Longhorned Digger bees), API - Western Honey bee.

\begin{tabular}{|c|c|c|c|c|c|c|c|c|c|c|}
\hline Researcher & $\begin{array}{l}\text { Year } \\
\text { of } \\
\text { Pub. }\end{array}$ & $\begin{array}{l}\text { Year of } \\
\text { Research }\end{array}$ & $\begin{array}{l}\text { Site I } \\
\text { Primary }\end{array}$ & $\begin{array}{l}\text { Site I } \\
\text { Secondary }\end{array}$ & $\begin{array}{l}\text { Site } 2 \\
\text { Primary }\end{array}$ & $\begin{array}{l}\text { Site } 2 \\
\text { Secondary }\end{array}$ & $\begin{array}{l}\text { Site } 3 \\
\text { Primary }\end{array}$ & $\begin{array}{l}\text { Site } 3 \\
\text { Secondary }\end{array}$ & $\begin{array}{l}\text { Site } 5 \\
\text { Primary }\end{array}$ & $\begin{array}{l}\text { Site } 5 \\
\text { Secondary }\end{array}$ \\
\hline \multirow[t]{2}{*}{ Muñoz } & I99I & 1989 & MIC & $\begin{array}{l}\text { LEP, RA, } \\
\text { HUM }\end{array}$ & --- & --- & --- & --- & --- & --- \\
\hline & & 1990 & MIC & None & --- & --- & $\begin{array}{l}\text { RA, } \\
\text { HUM }\end{array}$ & None & --- & --- \\
\hline \multirow[t]{2}{*}{ Erickson } & 1993 & I99I & MIC & RA & --- & --- & --- & --- & $\begin{array}{l}\text { HUM, } \\
\text { RA, } \\
\text { HYLE }\end{array}$ & None \\
\hline & & 1992 & MIC & None & --- & --- & --- & --- & $\begin{array}{l}\text { HUM, } \\
\text { RA, } \\
\text { BOM }\end{array}$ & None \\
\hline \multirow[t]{2}{*}{ Stone } & 1995 & 1993 & --- & --- & --- & --- & --- & --- & $\begin{array}{l}\text { HUM, } \\
\text { BOMC, } \\
\text { RA }\end{array}$ & $\begin{array}{l}\text { HAFA, } \\
\text { HATR }\end{array}$ \\
\hline & & 1994 & --- & --- & --- & --- & --- & --- & $\begin{array}{l}\text { HUM, } \\
\text { BOMC, } \\
\text { RA }\end{array}$ & $\begin{array}{l}\text { HAFA, } \\
\text { HATR }\end{array}$ \\
\hline Jones et. al & 1996 & I995 & $\begin{array}{l}\text { BOM, } \\
\text { LEP, } \\
\text { HUM }\end{array}$ & None & $\begin{array}{l}\text { HAL, } \\
\text { HUM }\end{array}$ & RA, LEP & $\begin{array}{l}\text { HAL, } \\
\text { MEL, } \\
\text { HUM }\end{array}$ & None & $\begin{array}{l}\text { MEL, } \\
\text { HUM, } \\
\text { HAL }\end{array}$ & BOM \\
\hline Atallah & $200 \mathrm{I}$ & 2000 & $\begin{array}{l}\text { HAL, } \\
\text { MEL, } \\
\text { HUM, } \\
\text { RA }\end{array}$ & API & $\begin{array}{l}\text { RA, } \\
\text { HUM, } \\
\text { HAL, } \\
\text { MEL }\end{array}$ & None & $\begin{array}{l}\text { HUM, } \\
\text { RA }\end{array}$ & $\begin{array}{l}\text { MEL, } \\
\text { HAL }\end{array}$ & $\begin{array}{l}\text { HUM, } \\
\text { RA }\end{array}$ & $\begin{array}{l}\text { MEL, } \\
\text { HAL }\end{array}$ \\
\hline Hoffman & 2010 & 2008 & $\begin{array}{l}\text { MIC, } \\
\text { API, } \\
\text { HUM }\end{array}$ & $\begin{array}{l}\text { MEL, } \\
\text { RA }\end{array}$ & $\begin{array}{l}\text { HUM, } \\
\text { RA, } \\
\text { API }\end{array}$ & MEL & $\begin{array}{l}\text { HUM, } \\
\text { RA, } \\
\text { API, } \\
\text { HAL, } \\
\text { MEL }\end{array}$ & MIC & $\begin{array}{l}\text { HUM, } \\
\text { RA, } \\
\text { API }\end{array}$ & MEL \\
\hline
\end{tabular}


TABLE 2. The percent contribution of each site ( $1,2,3, \& 5)$ expressed in percentage of the ration of the site visits to total visits by select primary pollinators and the raw number of visits across all seasons for years; 1995, 2000, \& 2008. Primary pollinator categories are HUM hummingbirds, HAL - Sweat bees, RA - Acton Giant Flowering-loving Fly, API - Western Honey bees, MEL - Longhorned Digger bees, MIC Long-tongued Digger bees, \& BOM - Bumble bees. Some pollinators were not among the primary pollinators for all years and may have a few to no visits represented.

\begin{tabular}{|c|c|c|c|c|c|c|c|c|c|}
\hline & \multicolumn{2}{|c|}{$\begin{array}{l}\text { Site I Pollinator } \\
\text { visits }\end{array}$} & \multicolumn{2}{|c|}{$\begin{array}{l}\text { Site } 2 \text { Pollinator } \\
\text { visits }\end{array}$} & \multicolumn{2}{|c|}{$\begin{array}{l}\text { Site } 3 \text { Pollinator } \\
\text { visits }\end{array}$} & \multicolumn{2}{|c|}{$\begin{array}{l}\text { Site } 5 \text { Pollinator } \\
\text { visits }\end{array}$} & \multirow{2}{*}{$\begin{array}{l}\text { Total Visits } \\
\text { by pollinator } \\
\text { by year }\end{array}$} \\
\hline & $\%$ & $\mathrm{~N}$ & $\%$ & $\mathrm{~N}$ & $\%$ & $\mathrm{~N}$ & $\%$ & $\mathrm{~N}$ & \\
\hline \multicolumn{10}{|l|}{2008} \\
\hline HUM & 4 & I83 & II.3 & 516 & 62 & 2,832 & 22.8 & $\mathrm{I}, 045$ & 4,576 \\
\hline HAL & I & 6 & $\mathrm{I} 2$ & 72 & 83.1 & 497 & 3.9 & 23 & 598 \\
\hline RA & 3.3 & 108 & I0.2 & 336 & 67.2 & 2,215 & 19.4 & 638 & 3,297 \\
\hline API & 22.4 & 690 & I6.I & 495 & 40.4 & $\mathrm{I}, 240$ & $2 \mathrm{I}$ & 646 & 3,070 \\
\hline MEL & 16 & $\mathrm{I} 44$ & $\mathrm{I} 2.4$ & I 12 & 47.7 & 430 & 24 & 216 & 902 \\
\hline MIC & 75.5 & 818 & 0 & 0 & 24.5 & 266 & 0 & 0 & $\mathrm{I}, 084$ \\
\hline $\mathrm{BOM}$ & 0 & 0 & 0 & 0 & 33.3 & 6 & 66.7 & $\mathrm{I} 2$ & I8 \\
\hline \multicolumn{10}{|l|}{2000} \\
\hline HUM & 2.7 & 35 & I3.2 & I7I & 27 & 349 & 57 & 739 & I,294 \\
\hline HAL & I 4.3 & 36 & 33.5 & 84 & 3I.I & 78 & 2I.I & 53 & $25 \mathrm{I}$ \\
\hline RA & 4.2 & 32 & 34.7 & 263 & 43.6 & 331 & I7.5 & 133 & 759 \\
\hline API & I00 & 8 & 0 & 0 & 0 & 0 & 0 & 0 & 8 \\
\hline MEL & $2 \mathrm{I} .2$ & 72 & 19.8 & 67 & 36.7 & I2I & 23.3 & 79 & 339 \\
\hline MIC & 0 & 0 & 0 & 0 & 0 & 0 & 0 & 0 & 0 \\
\hline BOM & 0 & 0 & 0 & 0 & 100 & 13 & 0 & 0 & I3 \\
\hline \multicolumn{10}{|l|}{ I995 } \\
\hline HUM & I8.I & 30 & I6.9 & 28 & I 4.5 & 24 & 50.6 & 84 & 166 \\
\hline HAL & 3.8 & 5 & 65.8 & IOI & I 5.2 & 24 & I7.I & 27 & I 58 \\
\hline RA & 21.6 & 8 & 35 & $\mathrm{I} 3$ & 29.7 & I I & I 3.5 & 5 & 37 \\
\hline API & 68.2 & I5 & I3.6 & 3 & 0 & 0 & I 8.2 & 4 & 22 \\
\hline MEL & 9.2 & 17 & 2.6 & 5 & 10.2 & 20 & 78.1 & I 53 & 196 \\
\hline MIC & 0 & 0 & 0 & 0 & 66.7 & 2 & 33.3 & I & 3 \\
\hline $\mathrm{BOM}$ & 75.5 & 83 & 6.4 & 7 & 2 & 2 & I 6.4 & 18 & IIO \\
\hline
\end{tabular}


TABLE 3. Years of pollinator observation, rainfall total for critical months of growing season (January through March) and total growing season rainfall occurring from July of the previous calendar year to June of the study year, with an average rainfall of $34.3 \mathrm{~cm}$ and mean annual temperatures with an average annual temperature of 17.54 Celsius.

\begin{tabular}{|c|c|c|c|}
\hline Year & $\begin{array}{l}\text { Rainfall Total for J, F, } \\
M(\mathrm{~cm})\end{array}$ & $\begin{array}{l}\text { Rainfall Total for Growing } \\
\text { Season }(\mathrm{cm}) \text { Wet/Dry } \\
\text { Above/Below } 34.3 \mathrm{~cm}\end{array}$ & $\begin{array}{l}\text { Temp } \\
\text { Mean Annual Temp } \\
\text { I7.54 Celsius }\end{array}$ \\
\hline 2008 & $\mathrm{I} 4.22$ & Dry $27.6 \mathrm{I}$ & High I8.69 \\
\hline 2000 & 16.87 & Dry 19.96 & High 2I.9I \\
\hline 1995 & 44.65 & Wet 54.89 & Slightly Low I7.52 \\
\hline 1994 & 20.27 & Dry 30.6I & Moderate I8.28 \\
\hline 1993 & 53.83 & Very Wet 72.3I & High I8.88 \\
\hline 1992 & 33.17 & Wet 39.93 & High I9.I4 \\
\hline I99I & 33.33 & Wet 35.74 & Moderate I8.29 \\
\hline 1990 & $\mathrm{I} 2.75$ & Dry 19.79 & High I8.66 \\
\hline 1989 & I I.9I & Dry 21.03 & High I8.83 \\
\hline
\end{tabular}

TABLE 4. The results of linear regression analysis of abundance for primary pollinators standardized by hours of observation correlated to mean annual precipitation for the year of observation and correlated to the mean annual precipitation for the previous year of observation (Asterisk * indicates a significant value of $<0.05$, a double asterisk indicates a significant value of < 0.0I, based on Rohlf and Sokal 1995).

\begin{tabular}{lllll}
\hline Pollinators & \multicolumn{2}{l}{$\begin{array}{l}\text { Mean Annual Precipitation for } \\
\text { Year of Observation }\end{array}$} & \multicolumn{2}{l}{$\begin{array}{l}\text { Mean Annual Precipitation for } \\
\text { Year Prior to Observation }\end{array}$} \\
& $\begin{array}{l}r \text { value } \\
\text { degree of } \\
\text { freedom }\end{array}$ & $\begin{array}{l}r \text { value } \\
\text { degree of } \\
\text { freedom }\end{array}$ \\
\hline Hummingbirds & $.7 \mathrm{I}$ & 5 & .56 & 5 \\
Sweat bees & .84 & 3 & .62 & 3 \\
Acton giant flower-loving flies & .67 & 5 & .61 & 5 \\
Western honey bees & .35 & 4 & .74 & 4 \\
Longhorned digger bees & $\mathrm{I}^{\text {*** }}$ & 2 & .78 & 2 \\
Long-tongued digger bees & .1 & 5 & .50 & 5 \\
Bumble bees & .26 & 4 & .1 & 4 \\
Butterflies and moths & .68 & 3 & $.92^{*}$ & 3 \\
White-lined sphinx moths & .22 & 3 & .22 & 3 \\
Native bees collectively & .68 & 4 & .80 & 4 \\
\hline
\end{tabular}




\section{PHOTOGRAPHS OF POLLINATORS}

Acton giant flower-loving fly, Rhaphiomidas acton (Mydidae), male.
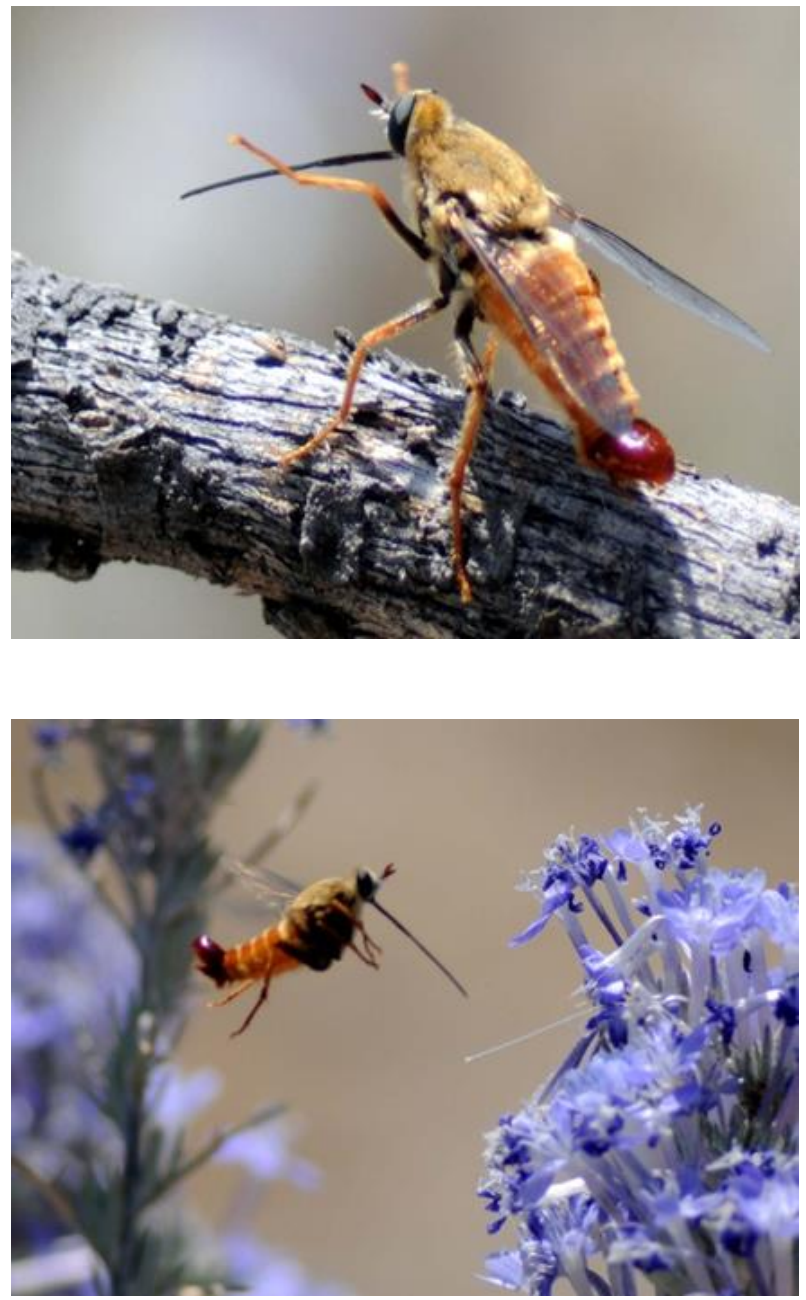

Sweat Bee, Augochlorella pomoniella (Halictidae)

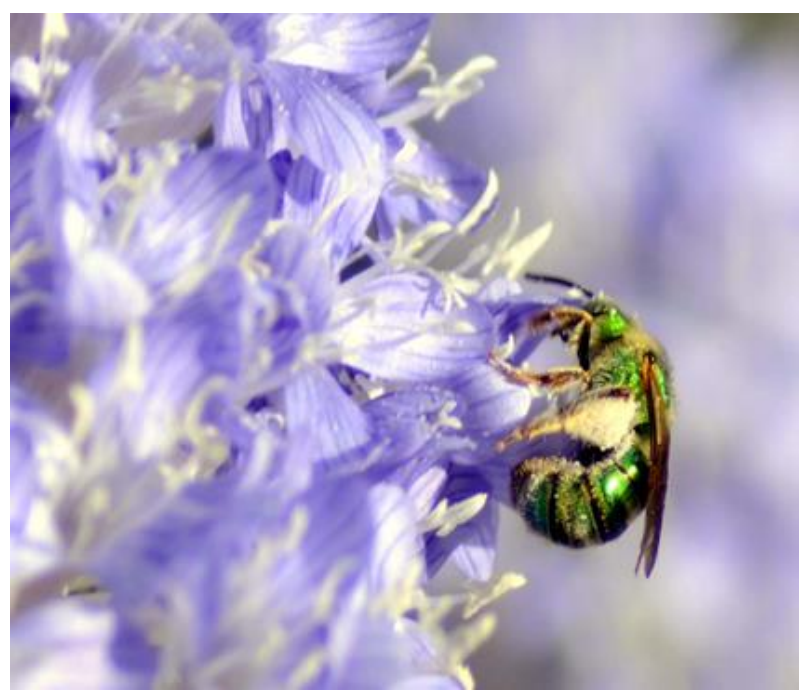

Digger Bees (Apidae).

Anthophora (subgenus Heliophila) sp.
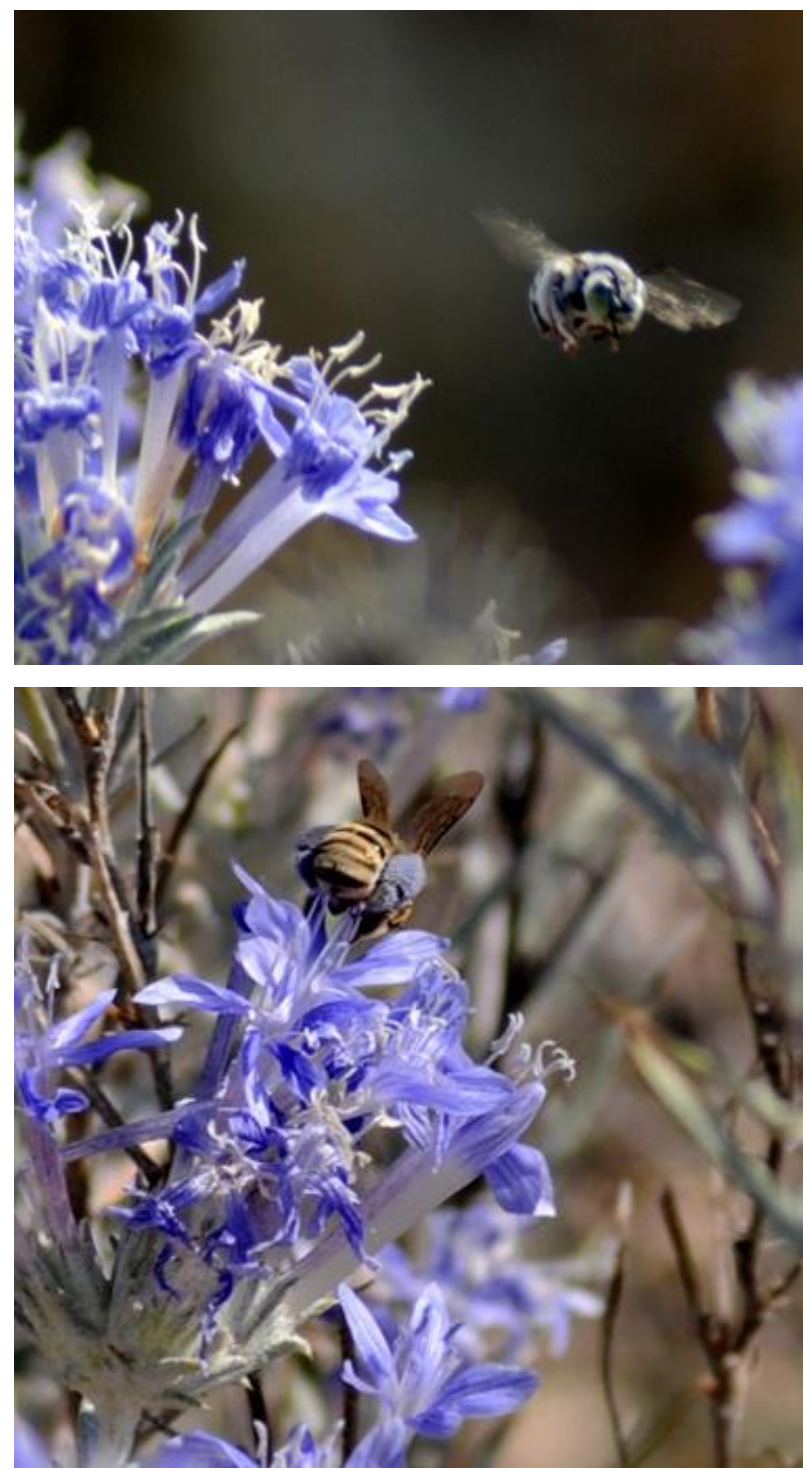

\section{REFERENCES}

Aigner PA (2003) The evolution of specialized floral phenotypes in a heterogenous pollination environment: Fitness trade-offs in a Dudleya (Crassulaceae) species complex. $\mathrm{PhD}$ dissertation, University of California, Riverside, California.

Aizen MA, Ashworth L, Galetto L (2002) Reproductive success in fragmented habitats: do compatibility systems and pollination specialization matter? Journal of Vegetation Science I3:885-892.

Aizen MA, Fensinger P (1994) Habitat fragmentation, native insect pollinators, and feral honey bees in Argentine "Chaco Serrano." Ecological Applications 4:378-392.

Alarcon R, Waser NM, Ollerton J (2008) Year-to-year variation in the topology of a plant-pollinator interaction network. Oikos II7:1796-I807.

Aldridge G, Campbell DR (2007) Variation in pollinator preference between two Ipomopsis contact sites that differ in hybridization rate. Evolution 6I(I):99-II0. 
Allen-Wardell, G, Bernhardt, P, Bitner R, Burquez A, Buchmann S, Cane J, Cox PA, Dalton V, Feinsinger P, Ingram M, Inouye D, Jones CE, Kennedy K, Kevan P, Koopowitz H, Medellin R, Medellin-Morales S, Nabhan GP. (1998) The potential consequences of pollinator declines on the conservation of biodiversity and stability of food crop yields. Conservation Biology I2(I): 8-I7

Ambrose, JD, Kevan, PG. (1990\} Reproductive biology of rare Carolinian plants with regard to conservation management. Pps. 57=63. In: Allen, GM, Eagles, PFJ, Price, SD. (Eriastrum). Conserving Carolinian Canada: Conservation Biology in the Deciduous Forest Region. University of Waterloo Press. Kitchener, Ontario, Canada.

Anderson GJ, Bernardello G, Stuessy TF, Crawford DJ (200I) Breeding System and Pollination of Selected Plants Endemic to Juan Fernández Islands. American Journal of Botany 88(2): 220233.

Ashman, TL, Knight TM, Steets JA, Amarasekare P, Burd, M, Campbell DR, Dudash MR, Mazer SJ, Johnston M, Mitchell RJ, Morgan, MT, Wilson WG. (2004) Pollen limitation of plant reproduction: ecological and evolutionary causes and consequences. Ecology 85: 2408-242I.

Atallah YC (200I) Assessing the reproductive biology of the Santa Ana River Woolly Star, Eriastrum densifolium ssp. sanctorum. M.S. Thesis, California State University, Fullerton, California.

Baldwin BG, Goldman DH, Keil DJ, Patterson R, Rosatti TJ, Wilken DH. Eriastrum (2012) The Jepson Manual: Higher Plants of California, second edition. University of California Press, Berkeley, CA. USA.

Bailey P, Kevan PG. (2017) Reproductive strategies matter for rare plant conservation: pollination, phenology, and mating in an endemic plant of the Sky Islands of Arizona, Erigeron lemmonii A. Gray (Lemmon's Fleabane) (Asteraceae). Western North American Naturalist 77(3): 385-397.

Basilio AM, Medan D, Torretta JP, Bortoloni NJ (2006) A yearlong plant pollinator network. Austral Ecology 31:975-983.

Bene F (1945) The role of learning in the feeding behavior of Blackchinned Hummingbirds. The Condor 47(I):3-22.

Boesi R, Polidori C, Andrietti F (2009) Biology of Lasioglossum (L.) majus (Hymenoptera: Halictidae), a largely solitary sweat bee with behavioral adaptations to communality. Journal of Entomology 27(3):36I-367.

Bosch M, Simon J, Molero J, Blanche C (1998) Reproductive biology, genetic variation and conservation of the rare endemic dysploid Delphinium bolosii (Ranunculaceae). Biological Conservation 86:57-66.

Boyd AE (2004) Breeding system of Macromeria viridiflora (Boraginaceae) and geographic variation of pollinator assemblages American Journal of Botany 91:1809-1813.

Bronstein JL, Alarcon R, Gever M (2006) The evolution of plantinsect mutualisms. New Phytologist 172:412-428.

Brys R, Jacquemyn H, Endels P, Van Rossum F, Hermy M, Triest L, De Bruyn L, Blust GDE (2004) Reduced reproductive success in small populations of the self-incompatible Primula vulgaris. Journal of Ecology 92:5-I4.

Buchmann SL, Nabhan GP (1996) The Forgotten Pollinators. Island Press, Washington, D.C.

Burk JH, Jones CE, Wheeler J. (1989) New Information on the rare Santa Ana River Woolly-Star. Fremontia 17 (3): 20-2I.

Burk JH, Jones CE (1993) Final Management Plan for the Santa Ana River Woolly Star, Eriastrum densifolium ssp. sanctorum. Prepared for The U.S. Army Corps of Engineers, Los Angeles
District, through subcontract with the Chambers Group, Inc., Irvine, California.

Burk JH, Jones CE (1993) Management Plan for the Santa Ana River Woolly Star, Eriastrum densifolium ssp. sanctorum. Report prepared for U. S. Army Corp of Engineers, Los Angeles District, by Chambers Group, Inc., Santa Ana, California.

Burk JH, Jones CE, Ryan WA, Wheeler J (2007) Floodplain vegetation and soils along the upper Santa Ana River, San Bernardino County, California. Madroño 54(2):I26-I37.

Burk, JH, Jones CE, Wheeler J, DeSimone S (1988) The Ecology of Eriastrum densifolium ssp. sanctorum (Milliken) Mason: Report prepared for U. S. Army Corps of Engineers, Los Angeles District, by Bright and Associates, Inc., Placentia, California.

Burk JH, Jones CE, Wheeler J, DeSimone S (1987) The ecology of Eriastrum densifolium sanctorum (Milliken) Mason: A preliminary report. Prepared for U.S. Army Corp of Engineers, Los Angeles District, under contract with Bright and Associates, Placentia, California.

Burkle LA, Marlin JC, Knight TM (2013) Plant-pollinator interactions over 120 years: Loss of species, co-occurrence, and function. Science 339:16II-I6I5.

Butz-Huryn VM (1997) Ecological impacts of introduced honey bees. The Quarterly Review of Biology 72(3):275-297.

Chamberlain SA, Schlising RA (2008) Role of Honey Bees (Hymenoptera: Apidae) in the Pollination Biology of a California Native Plant, Triteleia laxa (Asparagales: Themidaceae). Environmental Entomology 37(3):808-816.

Colla SR, Otterstatter MC, Gegear RJ, Thomson JD (2006) Plight of the bumble bee: Pathogen spillover from commercial to wild populations. Biological Conservation I29:46I-467.

Cox-Foster DL, Conlan S, Holmes EC, Palacios G, Evans JD, Moran NA, Quan P-L, Briese T, Hornig M, Geiser DM, Martinson V, vanEngelsdorp D, Kalkstein AL, Drysdale A, Hui J, Zhai J, Cui L, Hutchison SK, Simons JF, Egholm M, Pettis JS, Lipkin WI (2007) A metagenomic survey of microbes in honey bee colony collapse disorder. Science 318:283-287.

DeMarco Jr. P, Coelho FM (2004) Services performed by the ecosystem: forest remnants influence agricultural cultures, pollination, and production. Biodiversity Conservation I3: I245I255.

Diaz S, Tilman D, Fargione J, Chapin III FS, Dirzo R, Kitzberger T. (2006) Biodiversity Regulation of Ecosystem Services. In: Hassan $\mathrm{R}$, Scholes R, and Ash N. editors. Ecosystems and human wellbeing: Current state and trends. Findings of the Conditions and Trens Working Group (D.C). Island Press; 297-329.

Dorsett, DK (1996) Reproductive biology of the endangered Santa Ana River woolly-star, Eriastrum densifolium ssp. sanctorum (Milliken) Mason (Polemoniaceae). Master of Arts in Biology thesis, Department of Biological Science, California State Univeristy, Fullerton, California USA.

Dorsett DK, Jones CE, Burk JH (200I) The pollination biology of Eriastrum densifolium ssp. sanctorum (Polemoniaceae), an endangered plant. Madroño 48(4):265-27I.

Engel EC, Erwin R (2003) Linking pollinator visitation rate and pollen receipt. Am. J. Bot. 90:1612-I6I8.

Erickson M (1993) Optimal outcrossing and pollinator foraging distance in the Santa Ana River Woolly Star, Eriastrum densifolium ssp. sanctorum. M.A. Thesis, California State University, Fullerton, California, USA

Fischer M, Matthies D (1997) Mating structure and inbreeding and outbreeding depression in the rare plant Gentianella germanica (Gentianaceae). American Journal of Botany 84:1685-I692. 
Fleming TH, Sahley CT, Holland JN, Nason JD, Hamrick JL (200I) Sonoran Desert columnar cacti and the evolution of generalized pollination systems. Ecological Monographs. 7I:5I I530.

Galen C, Zimmer KA, Newport ME (1987) Pollination in floral scent morphs of Polemonium viscosum: a mechanism for disruptive selection on flower size. Evolution 4I:599-606.

Godt MJW, Hamrick JL (1995) Allozyme variation in two Great Smoky Mountain endemics: Cacalia regelia and Glyceria nubigena. J. Heredity 86:194-198.

Goodwillie C (200I) Pollen limitation and the evolution of selfcompatibility in Linanthus (Polemoniaceae). International Journal of Plant Sciences I62(6):I283-I292.

Greenleaf SS, Williams N, Winfree R, Kremen C (2007) Bee foraging ranges and their relationship to body size. Oecologia 152:589-596.

Herrera CM (1987) Components of pollinator "quality": Comparative analysis of a diverse insect assemblage. Oikos 50:7990.

Herrera, CM (1989) Pollinator abundance, morphology, and flower visitation rate: analysis of the "quantity" component in a plantpollinator system. Oecologia 80:24I-248.

Herrera CM (1995) Plant-vertebrate seed dispersal systems in the Mediterranean: ecological, evolutionary, and historical determinants. Annual Review of Ecology and Systematics 26:705727.

Heschel MS, Paige KN (1995) Inbreeding depression, environmental stress, and population size variation in scarlet gilia (Ipomopsis aggregata). Conservation Biology 9:126-I33.

Hobbs RJ, Huenneke LF (1992) Disturbance, diversity, and invasion: Implications for Conservation. Conservation Biology 6:324-337.

Hoffman FL (2010) Spatiotemporal variation in pollinator taxa on the Santa Ana River woolly star Eriastrum densifolium ssp. sanctorum (Milliken) Mason (Polemoniaceae). M.S. Thesis, California State University, Fullerton, California.

Holland RF (1986) Preliminary Description of the Terrestrial Natural Communities of California. State of California, The Resources Agency, Department of Fish and Game, Sacramento, California.

Jennersten O (1988) Pollination in Dianthus deltoides (Caryophyllaceae): effects of habitat fragmentation on visitation and seed set. Conservation Biology 2:359-366.

Kearns CA, Inouye DW (1997) Pollinators, flowering plants and conservation biology. Bioscience 47:297-307.

Kearns CA, Inouye DW, Waser NM (1998) Endangered mutualisms: the conservation of plant-pollinator interactions. Annual Review of Ecology and Systematics 29:83-II2.

Kevan, PG (1999) Pollinators as bioindicators of the state of the environment: species, activity and diversity. Agriculture Ecosystems and Environment 74:373-393.

Kremen C, Williams NM, Thorp RW (2002) Crop pollination from native bees at risk from agricultural intensification. Proc. Natl. Acad. Sci. USA. 99: 16812-16816.

Kremen C, Williams NM, Aizen MA, Gemmill-Herren B, LeBuhn, G, Minckley R (2007) Pollination and other ecosystem services produced by mobile organisms: a conceptual framework for the effects of land-use change. Ecol. Lett. I0: 299-3I4.

Lamont BB, Klinkhamer PGL, Witkowski ETF (1993) Population fragmentation may reduce fertility to zero in Banksia goodie - a demonstration of the Allee effect. Oecologia 94:446-450.
Martin J (1988) Different feeding strategies of two sympatric hummingbird species. The Condor 90(I):233-236.

Mayfield MM, Waser NM, Price MV (200I) Exploring the "most effective pollinator principle" with complex flowers: bumblebees and Ipomopsis aggregata. Annals of Botany 88:59I-596.

Motten AF (1986) Pollination ecology in the spring wildflower community of a temperate deciduous forest. Ecological Monographs 56:2I-42.

Muñoz AA (199I) Reproductive biology of the endangered Santa Ana River Woolly Star, Eriastrum densifolium ssp. sanctorum. M.A. Thesis, California State University, Fullerton, California.

Mustajarvi K, Siikamaki P, Rytkonen S, Lammi A (200I) Consequences of plant population size and density for plantpollinator interactions and plant performance. Journal of Ecology 89(I):80-87.

Ollerton J, Cranmer L (2002) Latitudinal trends in plant-pollinator interactions: are tropical plants more specialized? Oikos 98:340350.

Ollerton JR, Winfree R (20II) How many flowering plants are pollinated by animals? Oikos I20 (3): 32I-326.

Pasquet RS, Peltier A, Hufford MB, Oydin E, Saunier J, Paul L, Knudsen JT, Herren HR, Gepts P (2008) Long-distance pollen flow assessment through evaluation of pollinator foraging range suggests transgene escape distances. Proceedings of the National Academy of Sciences of the United States of America I05(36):I3456-I346I.

Pickett STA, White PS (1985) The Ecology of Natural Disturbance and Patch Dynamics. Academic Press, Inc., Orlando, Florida.

Potts SG, Vulliamy B, Dafni A, Ne'eman G, O’Toole CA, Roberts S, Willmer PG (2003) Response of plant-pollinator communities following fire: Changes in diversity, abundance, and reward structure. Oikos I0I:I03-II2.

Potts SG, Imperatriz-Fonseca V, Ngo HT, Aizen MA, Biesmeijer JC, Breeze TD (2016) Safeguarding pollinators and their values to human well-being. Nature 540: 220-229.

Proctor M, Yeo P, Lack A (1996) The natural history of pollination. Harper Collins, London.

Robertson C (1895) The philosophy of flower seasons, and the phaenological relations of the entomophilous flora and the anthophilous insect fauna. American Naturalist 29:97-I 17.

Schemske DW, Husband BC, Ruckelshaus MH, Goodwillie C, Parker IM, Bishop JG (1994) Evaluating approaches to the conservation of rare and endangered plants. Ecology 75:584-606.

Schemske DW, Horvitz CC (1984) Variation among floral visitors in pollination ability: A precondition for mutualism specialization. Science 225:519-52I.

Schoenherr AA (1995) A Natural History of California. University of California Press, Berkeley, California.

Sih A, Baltus MS (1987) Patch size, pollinator behavior, and pollinator limitation in catnip. Ecology 68:1679-1690.

Spears EE (1983) A direct measure of pollinator effectiveness. Oecologia 57:196-199.

Spira TP (200I) Plant-pollinator interactions: A threatened mutualism with implications for the ecology and management of rare plants. Natural Areas Journal 2I:78-88.

Stanford JA, Ward JV, Liss WJ, Frissell CA,Williams RN, Lichatowich JA, Coutant CC (1996) A general protocol for restoration of regulated rivers. Regulated Rivers: Research \& Management I2:39I-4I3.

Steffen-Dewenter I, Tscharntke T (I999) Effects of habitat isolation on pollinator communities and seed set. Oecologica I2I:432-440. 
Stone DR (1995) Pollinator effectiveness and assemblages in three populations of Eriastrum densifolium. M.A. Thesis, California State University, Fullerton, California.

Tepedino VJ, Mull J, Griswold TL, Bryant G (2014) Reproduction and pollination of the endangered Arctomecon humilis (Papaveraceae) across a quarter century: unraveling of a pollination web. Western North American Naturalist 74(3):3I I-324.

Torres E, Iriondo JM, Perez C (2002) Vulnerability and determinants of reproductive success in the narrow endemic Antirthinum microphyllum (Scrophulariaceae). American Journal of Botany 89:II7I-I I79.

UNFAO: Food and Agriculture Organization of the United Nations (2008) Agricultural Biodiversity in FAO. UNFAO, Rome. [online] URL: ftp://ftp.fao.org/docrep/fao/0IO/i0II2e/ iOI I2e.pdf (accessed November 2015).

U.S. Army Corps of Engineers (2000) Biological assessment Seven Oaks Dam, Santa Ana River mainstem project, San Bernardino County, California. Prepared by MEC Analytical Systems, Inc., Carlsbad, California, and Aspen Environmental Group, Agoura, California.

Vanbergen AJ, Initiative IP (2013) Threats to an ecosystem service: pressures on pollination. Front Ecol. Enviorn. II: 25I-259.

Waser NM, Ollerton J (2006) Plant pollinator interactions: from specialization to generalization. University of Chicago Press, Chicago, Illinois.

Western Regional Climate Center (2009) [online] URL: http://www.wrcc.dri.edu/CLIMATEDATA.html (accessed September 2009).
Wethington SM, West GC, Carlson BA (2005) Hummingbird conservation: Discovering diversity patterns in Southwest U.S.A. USDA Forest Service Proceedings RMRS-P-36:I62-I68.

Wheeler J (I99I) Seed and seedling ecology of Eriastrum densifolium ssp. sanctorum, an endangered floodplain endemic. M.A. Thesis, California State University, Fullerton, California.

Winter K, Adams L, Thorp R, Inouye D, Day L, Ascher J, Buchmann S (2006) Importation of Non-Native Bumble Bees into North America: Potential Consequences of Using Bombus terrestris and Other Non-Native Bumble Bees for Greenhouse Crop Pollination in Canada, Mexico, and the United States. A White Paper of the North American Pollinator Protection Campaign. August 2006.

York RP (1987) California's most endangered plants. In: Elias, TS (ed.). Conservation and Management of Rare and Endangered Plants. California Native Plant Society, Sacramento, California, p 109.

Young AG, Boyle TJB, Brown AHD (1996) The population genetic consequences of habitat fragmentation for plants. 1996. Trends In Ecology and Evolution II:4I3-4I8.

Zedler JB, Callaway JC, Sullivan G (200I) Declining biodiversity: Why species matter and how their functions might be restored in California tidal marshes. BioScience 5I(I2):I005-I0I7.

Zembal R, Kramer KJ (1984) The known limited distribution and unknown future of Santa Ana River Woolly Star (Eriastrum). Crossosoma IO(5):I-8. 